\title{
Studies in the genus Cystoderma
}

\author{
HARRI HARMAJA
}

\begin{abstract}
HARMAJA, H. 1979: Studies in the genus Cystoderma. - Karstenia 19: 25-29.
An attempt is made to clarify the nomenclature of Cystoderma jasonis (Cooke \& Massee) Harmaja (C. amianthinum (Fr.) Konr. \& Maubl. var. longisporum Kühn.) and the species is compared with the closely related $C$. amianthinum. It has cyanophilic spore and basidium walls and binucleate spores, and is common in Finland. C. amianthinum was found to have dextrinoid and cyanophilic sclerobasidia. Cystoderma lilacipes Harmaja ( $C$. 'longisporum (Kühn.) Heinem. \& Thoen' var. purpurascens Heinem. \& Thoen, nom. inval.) is compared with the closely related $C$. jasonis. Hitherto the species has been known from one Belgian locality only; now 12 localities are reported from Finland. Cystoderma tuomikoskii Harmaja and Cystoderma intermedium Harmaja, two new species closely related to $C$. fallax Smith \& Sing., are described on the basis of Finnish material. Cystoderma terreii (Berk. \& Broome) Harmaja is regarded as the legitimate name for C. cinnabarinum (Secr.) Konr. \& Maubl. The author agrees that the genus Cystoderma Fayod should be placed in the family Tricholomataceae. Some author citations are corrected.
\end{abstract}

Harri Harmaja, Botanical Museum, University of Helsinki, Unioninkatu 44, SF00170 Helsinki 17, Finland

\section{Cystoderma jasonis}

Agaricus Jasonis Cooke \& Massee in Cooke, Grevillea 16: 77. 1888. - Armillaria Jasonis (Cooke \& Massee) Sacc., Syll. fung 9: 12. 1891. - Cystoderma jasonis (Cooke \& Massee) Harmaja, Karstenia 18: 29. 1978. - Holotype (K) and isotype (NY) examined: 'England, Carlisle, leg. Dr. Carlyle'.

Lepiota amianthina var. longispora Kühn., Bull. Soc. Mycol. France 52: 204. 1936 (nom. inval.; without Latin description). - Cystoderma amianthinum var. longisporum ('Kühn.') Smith \& Sing., Pap. Michigan Acad. Sci. Arts Lett. 30: 114. 1945; Locq., Bull. Soc. Linn. Lyon 14: 94.1945 (nom. inval.: basionym invalid.). Cystoderma amianthinum var. longisporum (Kühn.) ex Kühn., Bull. Soc. Linn. Lyon 38: 185. 1969 (type from France). - Cystoderma longisporum ('Kühn.') Heinem. \& Thoen, Bull. Soc. Mycol. France 89: 16. 1973 (nom. inval.: the basionym is Kühner's invalid name from 1936).

?Cystoderma amianthinum var. sublongisporum Sing. in Smith \& Sing., Pap. Michigan Acad. Sci. Arts Lett. 30: 112. 1945. - Cystoderma sublongisporum (Sing.) Sing., The Agaricales in modern taxonomy: 479. 1975 (not validly published: listed only, reference to basionym lacking).

?Cystoderma amianthinum var. longisporum Wasser ('Kühn. ex Wasser'), Ukrajins'kij Bot. Z. 35: 518. 1978 (type from U.S.S.R.; illegitimate as later homonym, at least).

Study of the genus Cystoderma Fayod in Finland revealed that some taxonomic and nomenclatural revision was required. As suggested by Heinemann \& Thoen (1973), the present taxon proved to deserve specific rank. C. jasonis has often been found growing in the same habitat as $C$. amianthinum (Fr.)
Konr. \& Maubl. in Finland, but the species are readily distinguished from each other macroscopically, even in the field.

The above list is an attempt to clarify the somewhat intricate nomenclature. At the specific level, Agaricus jasonis is by far the oldest name, and although Smith \& Singer (1945) supposed it to mean the same as Kühner's Lepiota amianthina var. longispora, they did not examine the types of $A$. jasonis. $C$. jasonis is the taxon with fairly long spores. All authors have agreed that the specific name $C$. amianthinum (Scopoli ex Fries) has to be retained for the shortspored taxon, obviously because it is far more frequent in Central Europe, the area where Scopoli collected his fungus.

The differences found between $C$. jasonis and the closely related $C$. amianthinum s. str. by Kühner (1969) and Heinemann \& Thoen (1973), were generally discernible and valid in representative Finnish material as well. Supplemented by a couple of observations of mine, the characters differentiating C. jasonis are: (1) the pileus, the ground of the stipe, and the granules on the latter are mostly somewhat darker brown, both when fresh and when dry, (2) the stipe apex at times has a purplish tinge, especially when dry, (3) the sphaerocyst granules on the cap and stipe are generally slightly larger and more prominent, and apparently more persistent, (4) the gills are yellowish buff, vs. whitish in $C$. amianthinum (though fairly distinct in fresh not too 


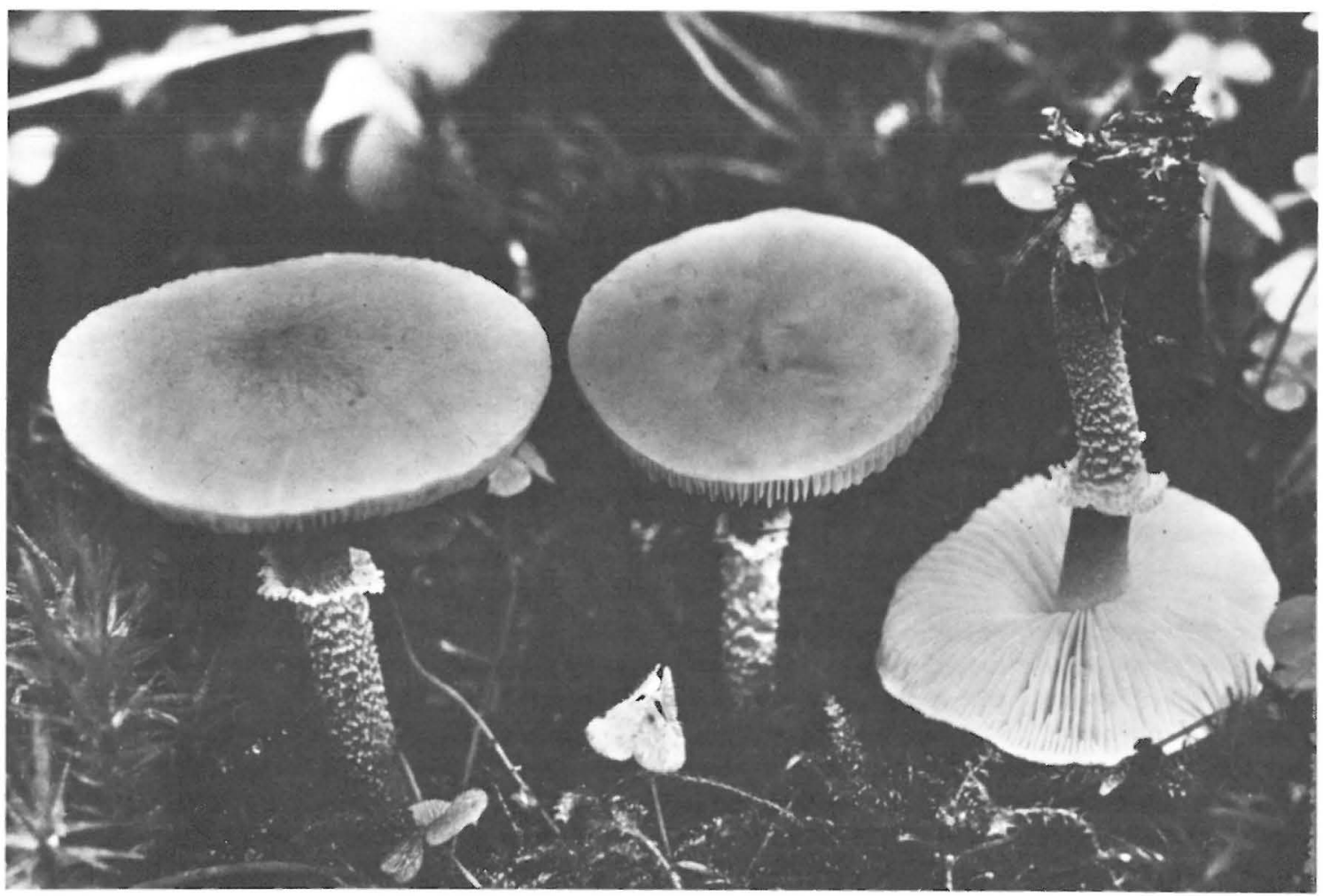

Fig. 1. Cystoderma intermedium fresh in situ, in about natural size. Part of the basidiocarps of the type collection. Photo: Mauri Korhonen.

'cinnabarinus' was unfortunately not recognized at the specific level until 1874. According to the 'Code', 'Terreii' has priority and should be used if the fungus is accorded specific rank (which it clearly deserves). Smith \& Singer (1945) were aware of the existence of A. terreii, but for some reason did not pay attention to the possible nomenclatural consequences and did not examine the type.

\section{Nomenclatural and other notes}

Heinemann \& Thoen (1973) consider that Cystoderma should be placed in the family Tricholomataceae rather than in Agaricaceae or Lepiotaceae. I agree with them, especially because none of the species of Cystoderma has free lamellae.

Many of the currently used author citations of the European species of Cystoderma are incorrect. The main reason for this situation is the failure of mycologists to notice that Fayod, who established the genus, never used the specific epithets, which now have to be considered, in connection with the generic epithet Cystoderma. In other words, Fayod did not make any of the required new combinations in Cystoderma. A search through the old literature suggests that the combination Cystoderma granulosum was first made by Kühner (1926). The combinations $C$. amianthinum, $C$. carcharias and the illegitimate $C$. cinnabarinum were first made in the 'Icones selectae fungorum' of Konrad and Maublanc. Besides partly appearing in the index of their work, the combinations are found in the third fascicle, printed on 31 May 1927, in the discussion part ('Observations') of the coloured plate no. 238 showing $C$. cinnabarinum (the last-named combination of course also as the heading of the plate). The combination Cystoderma ambrosii was first made by Singer (1943), not by Smith \& Singer (1945).

No less than eleven species of Cystoderma are now known to occur in Finland (Harmaja 1974b, 1978, and this paper, Tuomikoski 1976); this is the greatest number of species known from any country, except the U.S.A. The Finnish species are listed below with 
the correct author citations (Secretan is provisionally retained as the first author of $C$. carcharias, although the validity of his nomenclature has recently been questioned): C. adnatifolium (Peck) Harmaja, $C$. ambrosii (Bres.) Sing., C. amianthinum (Fr.) Konr. \& Maubl., C. carcharias (Secr.) Konr. \& Maubl., C. fallax Smith \& Sing., C. granulosum (Fr.) Kühn., C. intermedium Harmaja, C. jasonis (Cooke \& Massee) Harmaja, C. lilacipes Harmaja, C. terreii (Berk. \& Broome) Harmaja, and C. tuomikoskii Harmaja.

Acknowledgements. The loans of Cystoderma types provided by the Royal Botanic Gardens at Kew (K) and the New York Botanical Garden (NY) are gratefully acknowledged. I am also very grateful to Dr. Lars Fagerström (Botanical Museum of University, Helsinki), who drew my attention to the existence of $C$. lilacipes by showing me well-preserved specimens of the species. Mr. Mauri Korhonen (Botanical Museum of University, Helsinki) took the excellent photograph of the type of $C$. intermedium.

\section{References}

Harmaja, H. 1974a: A revision of the generic limit between Clitocybe and Lepista. - Karstenia 14: 82-92.

-"- 1974 b: Notes on two agarics described in North America: 1. Rhodocybe smithii nom.nov., a new name for Clitocybe piperata A.H. Smith. 2. Cystoderma adnatifolium (Peck) n.comb., a species new for Europe. - Karstenia 14: 121-122.

-"-1978: New species and combinations in the pale-spored Agaricales. - Karstenia 18: 29-30.

Heinemann, P. \& Thoen, D. 1973: Observations sur le genre Cystoderma. - Bull. Soc. Mycol. France 89: $5-34$, pl. 1 .

Kühner, R. 1926: Contribution à l'étude des Hyménomycètes et spécialement des Agaricacés. - Le Botaniste 17: 5-218.

-"- 1969: Cystoderma amianthinum (Scop. ex Fr.) Fayod, var. longisporum (Kühner) Smith et Singer et var. sublongisporum Singer. - Bull. Soc. Linn. Lyon 38: $178-188$.

von Schulmann, O. 1961: Zur Kenntnis der Basidiomyceten Finnlands. - Karstenia 5: 5-99.

Singer, R. 1943: Das System der Agaricales 3. - Ann. Mycol. 41: 1-189.

Smith, A.H. \& Singer, R. 1945: A monograph on the genus Cystoderma. - Pap. Michigan Acad. Sci. Arts Lett. 30: $71-124,5 \mathrm{pls}$.

Tuomikoski, R. 1976: Ryhäkkäät, Cystoderma. - In: Ulvinen, T. (ed.), Suursieniopas: 137-138. Helsinki.

Accepted for publication

on November 17, 1978 